\title{
Inter-colonial networks and revolutionary ferment in eighteenth-century Curaçao and Tierra Firme
}

\author{
Linda M. Rupert
}

Whether or not the slave uprisings that occurred within three months of each other in Curaçao and Coro in 1795 were part of a coherent conspiracy remains open to debate, and it may never be resolved with irrefutable evidence. There is no doubt, however, that the revolts were connected at a much deeper level: people of African descent were part of well-established communications and exchange circuits that had linked the two areas for over one hundred years. In fact, ties between Curaçao and Tierra Firme, most especially the area around Coro, had a much longer history, one which predated the Dutch and even the Spanish presence in the Caribbean, and which was integrally tied to the area's geography. ${ }^{1}$ Throughout the seventeenth and eighteenth centuries, once the island and the nearby mainland became part of separate colonial spheres (the Dutch and the Spanish, respectively) denizens from across the socio-economic spectrum forged their own inter-colonial networks, especially via contraband trade (Rupert 2006:35-54). The links that people of African descent developed between Curaçao and Tierra Firme were embedded in these wider trans-colonial connections and went much deeper than any possible slave conspiracy.

\section{OVERLAPPING JURISDICTIONS}

Markedly different degrees and styles of imperial management shaped the character of the inter-colonial ties that developed between the two areas. For the Dutch in Curaçao, territorial hegemony was almost incidental to the development of empire. Control over this small Caribbean nodal point, with its strategic location and excellent deep-water harbour, was sufficient for opening the broader commer-

1 Haviser 1987:11, 51-4; 73-9, 140-9; Watlington 2003:31-2; Whitehead 1995: Introduction. 
cial networks that were necessary to develop and sustain their vigorous Caribbean and Atlantic trade. ${ }^{2}$ The small, arid island of Curaçao was tightly and continuously governed by the Amsterdam Chamber of the Dutch West India Company (WIC), which had a full complex at Fort Amsterdam, perched at the entrance to the capacious harbour on St. Anna Bay. The establishment of a regional trade centre at Curaçao was a logical extension of WIC activities throughout the Atlantic and Caribbean (Den Heijer 2003). Because Curaçao lacked the climate and soil for agricultural production, the compact port of Willemstad, adjacent to the fort, soon became the motor of the island economy. The WIC's decision to open Curaçao to free trade in 1675, an unusual move for the times, stimulated the island's role in inter-colonial commerce, most of it illicit from the point of view of other imperial powers. Even while the Dutch successfully maintained tight and continuous political jurisdiction over Curaçao their primary focus was the lucrative economic gain provided by much more extensive and amorphous inter-colonial trade circuits.

Spanish imperial control over Tierra Firme, in contrast, was both more tenuous and more concerned with territorial domination. Initially under the jurisdiction of the Viceroyalty of Santo Domingo, located on the island of Hispaniola hundreds of miles to the north, Tierra Firme was transferred to the newly-created Viceroyalty of New Granada in 1717 in an effort to improve contact with representatives of the Spanish Crown and also to discourage the growing contraband trade. However, effective overland communication within this vast and varied continental jurisdiction proved even more unreliable than the maritime connections with Hispaniola, and so throughout the eighteenth century Tierra Firme repeatedly was transferred between the viceroyalties of Santo Domingo and New Granada (Briceño 1965:41$51)$. Due to this fluctuating authority and to the difficult, unreliable communications with either colonial seat of power, governance of much of Tierra Firme was chaotic throughout the eighteenth century. Lines of colonial authority often were unclear over the sparsely inhabited coast (Castillo 1981:113; Ferry 1989:114-7). Such administrative confusion, along with overall Spanish neglect of the region, spurred the development of a thriving contraband trade by a variety of people across the socio-economic spectrum. This included local authorities who often were uncertain about the precise imperial chain of command and their own authority and position in the hierarchy, but were

2 For different perspectives on the relative roles of commercial maritime networks and territorial control in the development of the Dutch imperial project see Schmidt 2009:163-87; Enthoven 2003:17-47; Seed 1995:154-60. More generally, Lauren Benton has argued that territorial control often was an 'incidental aim of imperial expansion' in the age of European empires (Benton 2010:2). 
eager to placate their local constituents and to seize lucrative opportunities to improve their own lot. Thus, Spain's inability to exercise territorial hegemony was also reflected in its lack of control over the region's economy and commercial circuits.

Tierra Firme, easily accessible because of favourable winds and currents and just seventy kilometres away, was a particularly attractive market for Curaçaoan merchants. It was filled with eager trade partners who provided a variety of coveted commodities, especially cacao and tobacco, to be traded on the regional and Atlantic markets. ${ }^{3}$ Tierra Firme functioned de facto as the vast economic hinterland for Curaçao's port of Willemstad. The area around Coro, at the base of the Paraguaná Peninsula, developed particularly close ties to the island. ${ }^{4}$ Trade with Tierra Firme made up fully half of Curaçao's total shipping throughout the second half of the eighteenth century (Klooster 1998:175). By the mid-eighteenth century entire areas of Tierra Firme were much more closely tied to Curaçao than to Spain (Aizpurua 1993:293). Inhabitants of both areas depended on the inter-colonial trade for their livelihood. Smuggling became the economic foundation of broader ties that developed between the two areas. It played out differently for the two European powers, representing success for the Dutch in developing and controlling the lucrative commercial circuits that formed the basis of their dominion, and failure for the Spanish in protecting both the territorial integrity and the mercantile exclusivity of their colonial possession.

If Tierra Firme functioned as Curaçao's economic hinterland, the roles were somewhat reversed and more complicated in the religious realm. This, too, was not so much due to carefully devised imperial policies as to colonial realities. Colonialism often led to messy situations on the ground, ones which did not always fit into the neat categories devised by authorities in distant Europe. Religious jurisdiction cut across lines of political authority. Curaçao had been under the umbrella of the Roman Catholic Church in Tierra Firme during the 135 years that the Spanish ruled the island (14991634). Even after the Dutch seized the island in 1634 the Roman Catholic Church considered Curaçao to remain under the control of Tierra Firme, an arrangement that was accepted at least tacitly by the Dutch West India Company. The so-called 'ABC islands' (Aruba, Bonaire, and Curaçao) fell under the administration of

3 The complexity and particularities of the contraband trade between Curaçao and Tierra Firme have been well documented. See especially Klooster 1998; Aizpurua 1993; Arauz 1984.

4 Socio-cultural, economic, religious, and political ties between Curaçao and Coro had deep historical roots, which also dated from pre-Colombian times and were strengthened during Spanish rule. For example, see Archivo General de Indias (hereafter AGI), Patronato 18 R3. 
the Bishopric of Coro until 1637 when, due to internal reorganization within the Roman Catholic Church, they were transferred to the Bishopric of Caracas (Brada 1953). Curaçao's Roman Catholic inhabitants retained close religious ties to Coro even after the transfer. Although the Church did not officially authorize any priests to visit the island for over four decades after the Dutch takeover there were some reports of unofficial, semi-clandestine visits by itinerant priests. ${ }^{5}$ While apparently turning a blind eye to these occasional visits the Dutch made some effort to limit more formal clerical contact and to exercise some level of at least nominal jurisdiction in the religious sphere. In 1661 the Dutch States General required that any Catholic priest who wished to settle on the island obtain a permit from the company (Brada 1956:40). ${ }^{6}$ This had the result of further encouraging the visits of itinerant priests, many of whom regularly arrived en route to and from other destinations around the Atlantic since Curaçao offered by far the most frequent, varied, and reliable transportation connections in the southern Caribbean. ${ }^{7}$

The Spanish formalized the role of visiting priests to the island in 1677, just two years after Curaçao became a free port. As part of an extensive pastoral letter encouraging evangelization on the island the Bishop of Caracas authorized any priests who arrived there to celebrate mass, perform sacraments, and generally attend to the spiritual needs of local Catholics, without needing prior or formal approval from the Church hierarchy (Felice 1982:394). This proved to be a highly effective way for the Roman Catholic Church to maintain an ongoing influence over Curaçao's population (especially slaves) and to minister to their spiritual needs without engaging in any political entanglements, and without having to obtain authorization of the Dutch States General or the WIC. Between 1680 and 1707 over fifty Roman Catholic priests visited Curaçao; thereafter virtually all of the island's denizens of African descent, enslaved and free, were baptized Catholics (Felice 1982:393-6). Throughout the eighteenth century a steady stream of priests from Spanish America continued to visit Curaçao, some secular, others members of religious orders (Lampe 2001b:108-9). Many were in transit; others stayed for extended periods of time.

In effect, the regular visit of Roman Catholic priests allowed the Spanish to have extensive influence over Curaçao's inhabitants, especially the majority of African descent, by proxy, accomplish-

$5 \quad$ Gehring and Schiltkamp 1987:103; Gonzalez 1990:41; Felice 1982:391-2.

6 Apparently they reissued it in 1705, perhaps indicating that it largely had been ignored in the interim (Schunk 1990:129).

7 Felice 1982:393; Schunk 1990:129; Lampe 2001a:131. 
ing one of the major expressed aims of the empire - the propagation of the Roman Catholic faith - in the colonial territory of a rival Protestant power. ${ }^{8}$ The Spanish thus maintained a degree of non-official religious control over Curaçao via the Roman Catholic Church, just as the Dutch had economic power over Tierra Firme via inter-colonial trade. Like smuggling, the regular visit of Roman Catholic priests to Curaçao provided an opportunity for intercolonial exchanges that directly engaged the needs and aspirations of colonial inhabitants. At the same time these inter-colonial networks allowed each power to exercise a certain degree of control in its preferred sphere of influence, well beyond the boundaries of official imperial demarcations. In the case of Curaçao and Tierra Firme, religious and economic spheres of influence did not correspond neatly to political demarcations. Nor were they entirely separate; many priests were involved in smuggling. ${ }^{9}$

\section{SMUGGLING SLAVES}

By the mid-eighteenth century illicit inter-colonial commerce had become the bedrock of a complex, multi-faceted exchange network that bound Curaçao and Tierra Firme across the imperial divide. Smuggling not only dominated economic ties between the two areas, it also shaped socio-cultural interactions and even the emerging contours of the colonial legal system in Tierra Firme. People of African descent, enslaved and free, played a central role in these inter-colonial trade networks. Enslaved Africans were an important early commodity that was shipped from Curaçao to Tierra Firme through the contraband trade and often opened the way for other forms of smuggling. Alongside the official trade that took place via the asiento de negros in the last quarter of the seventeenth century Curaçao also developed a thriving clandestine commerce in human cargo (Postma 1990:29-36). In years when supply from Africa greatly outstripped the abilities of the official trade channels to distribute the chattel legally, this illegal commerce was an important safety valve for the entire system, allowing it, in practice, to operate along the lines of a free market. It was clear to the Spanish Crown, and to everyone else involved, that the asiento often

8 The degree to which the Dutch cared about Christianization of their colonial subjects has been the subject of historiographic debate (Oostindie 1996).

9 Schabel, 'Dagboek' (Nationaal Archief Nederlandse Antillen, Willemstad, Curaçao); Gehring and Schiltkamp 1987:103; Felice 1982:392 fn 9; Gonzalez 1990:36, 41; Schunk 1997:96, 100. 
was used as a front for a far more extensive, more lucrative trade in a wide variety of contraband goods to Spain's neglected American colonies. For example, the license that the Spanish Crown issued to Juan Barroso del Pozo in February 1680 noted how the Dutch 'furtively introduce' a variety of products, including 'clothing, fruit, and, merchandize, which results in grave damages', and it specifically prohibited the introduction of any such goods alongside the human commodities. ${ }^{10}$ This prohibition blatantly was ignored. The clandestine trade also opened multiple opportunities for cultural and economic exchanges between Curaçao and Tierra Firme.

The contraband trade in slaves to Tierra Firme raised difficult issues for the Spanish Crown, which was acutely aware of the labour shortage on the isolated mainland coast, but loathe to sanction smuggling to its colonies in any form, and especially leery of the developing relationship between Curaçao and Tierra Firme. By the end of the seventeenth century the illicit import of enslaved Africans to the Spanish mainland was so prevalent that it caused the Crown a legal headache: what to do with the existence of large numbers of enslaved workers whose labour was vitally needed in the under-populated areas, but whose very presence testified to the brazenly successful and highly illegal trade that inhabitants conducted with the nearby Dutch island? Perhaps surprisingly, the Crown's solution was to offer freedom to these slaves. Between 1685 and 1705 the Spanish Crown issued three strongly worded Royal Decrees aimed at addressing the problem of these so-called 'blacks of bad entry' (negros de mala entrada), threatening to grant freedom to any slave on the mainland whose owner did not have a legitimate bill of purchase via the asiento. ${ }^{11}$ In 1685 the Crown granted freedom to all slaves in Tierra Firme whose owners could not produce such a document, and further required the owner to pay the asiento for the full value of the slave. In early 1689 the Governor of Mérida petitioned the Crown to allow local slaveholders to keep without reprisals the many bondsmen they had illegally purchased via Curaçao, citing the ease with which foreigners trafficked on the vast, open coast. But the king held fast. In 1690 the Crown issued another decree, specifically mentioning the widespread fraud committed by the Coymans asiento, based on Curaçao, which, it claimed, had 'introduced over 400 heads of bad entry, of which no more than sixteen have been captured'. ${ }^{12}$ In 1692 , in specific

10 'Licencia para comprar esclavos negros en Curazao' 10-02-1680 in Marley 1985: Document II: no pagination.

11 Marley 1985: Documents III and V: no pagination.

12 Real cédula 30-01-1690 in Marley 1985: Document V: no pagination. 
response to the governor's petition, Charles once again ordered all such slaves to be freed, citing the full text of the previous Royal Decrees of 1685 and $1690 .{ }^{13}$ A Royal Decree issued in 1705 again echoed the Crown's earlier concern, fined owners in Tierra Firme two hundred pesos for each illicitly obtained slave, and granted freedom to the slaves. ${ }^{14}$

It is unclear to what extent these decrees or the fines were enforced, and how many enslaved Africans, if any, actually obtained their freedom in this way. The very fact that four such similar decrees were issued in twenty years is powerful evidence not only of the trade itself, but of the Crown's ineffectiveness in combating it. Similarly, the failure of these and other official efforts to curb the clandestine trade indicates its appeal not only for Curaçaoan traders but also many different denizens of Tierra Firme. The Spanish Crown knew that the illicit slave trade was used as a cover for the broader contraband trade in other commodities. Colonial officials in Tierra Firme, for their part, were aware of smuggling's importance for the local economy. No doubt they felt conflicting loyalties. The Crown appears to have valued its protectionist policies above the rights of slave holders to own chattel, which had been obtained outside of approved distribution networks. ${ }^{15}$ The smuggled slaves entered Tierra Firme as valuable contraband commodities and, once they were there, often continued to participate in illicit inter-colonial commerce as both labourers and traders.

While some slaves were being smuggled from Curaçao to Tierra Firme to continue in bondage, others smuggled themselves along the same route in pursuit of freedom. The documented number of runaways who escaped from the island to the mainland rose dramatically in the last quarter of the seventeenth century, spurred by the expansion and consolidation of illicit inter-colonial commercial networks (including, perhaps ironically, the slave trade). The dozens of small sea-craft that sailed regularly between the two areas provided ample opportunity for enslaved Afro-Curaçaoans to flee. Coro was a particularly favourite destination for Afro-Curaçaoans who sought to escape enslavement, just as it was a magnet for illicit inter-colonial commerce. This was not a coincidence. Like traders, fugitives took advantage of the favourable geography: ocean currents and trade winds moved towards the southwest, pushing

13 'Bando sobre negros "de mala entrada"' 24-03-1692 in Marley 1985: Document V: no pagination.

14 Real cédula 25-10-1705 in Troconis 1969:240-3.

15 The opinions of the slaves in question are not recorded, although one can assume that they would have welcomed opportunities to obtain freedom. 
vessels that departed from Curaçao's shores directly to the base of the Paraguaná Peninsula. As a smuggling centre already established by the $1650 \mathrm{~s}$, frequented by small-scale merchants and seafarers, Coro offered ample opportunities for runaways to work in the contraband trade and to become part of local networks (Gehring and Schiltkamp 1987:104; Aizpurua 2001:69-102). Authorities in Coro apprehended at least forty-four runaway slaves from the island between 1690 and 1702. ${ }^{16}$ By 1704 there were so many fugitive Afro-Curaçaoans living in the area around Coro that the local government considered rounding them up and centralizing them in a special, newly-created town (Gonzalez 1987:120-1).

It was in this context of rampant smuggling of people and goods, and continued marronage from Curaçao, that the Spanish Crown issued two reales cédulas in 1704 and 1711, which offered freedom and land to enslaved Afro-Curaçaoans who arrived in Tierra Firme. ${ }^{17}$ The process was not automatic; new arrivals had to petition in colonial courts separately for freedom and land, and they had to provide documents and often testimony of third parties proving that they had converted to Catholicism and had been baptized after arriving in Spanish territory. ${ }^{18}$ The conversion requirement was a bit of a ruse since Spanish authorities at every level had ample evidence that virtually the island's entire enslaved population already was Roman Catholic. After all, they had been overseeing evangelization efforts there for decades. ${ }^{19}$ Here again, people of African descent had a major impact on the development of Spanish colonial legal frameworks.

These Royal Decrees provided one way for Spain to populate Tierra Firme with potentially loyal subjects. Slaves from Curaçao would metamorphose from being lucrative commodities in a trade that challenged Spanish imperial interests - or fugitives who were slated to live furtively on the margins of society - into devoted subjects of the Crown, who, presumably, were grateful for the opportunities for their new lives as fully vested citizens. Similarly, in this view, the Curaçaoan merchants who participated in contraband

16 Archivo General de la Nación Caracas, Venezuela (AGN) Diversos (D) I folio 408-14; Castillo 1981:343, 345-6.

17 AGN Reales Cédulas (RC) Sección la Vol X; Torres 1997:49-55; Castillo 1981:350, 600; Ferry 1989:110-3. For discussion of the wider context of these decrees see Rupert 2009:362-7. 18 For example, see Archivo de la Academia National de la Historia (AANH) Sección Civiles, Esclavos (SC-E) T 1742 CGPRSUZ Exp. \#9.

19 The wording of the decrees, including the provision for conversion, is virtually identical to that of other such reales cédulas that were issued for other parts of the circum-Caribbean, indicating that the provision may have been a standard one that did not account for the particular realities of the area encompassing Curaçao and Tierra Firme. 
trade, most of whom were slave-owners, would now be seen as enemies bent on re-enslaving their former chattel rather than as attractive trade partners. Attracting fugitive slaves also drained labour from rival European powers. In practice, the fugitives were quite capable of using the system to their own ends. Like so many others who were affiliated with illicit inter-colonial trade they seemed perfectly content to maintain dual loyalties, nominally professing their new allegiance to the Crown while keenly looking out for their own interests.

In the decades after these decrees were issued, marronage from Curaçao to Tierra Firme skyrocketed, spurred by the close ties between the areas created by contraband trade, as well as by the framework that the reales cédulas provided.$^{20}$ Coro was a particularly popular destination due to its proximity and accessibility, but records indicate that enslaved Curaçaoans travelled to a variety of different destinations along hundreds of miles of Tierra Firme's Caribbean littoral. The coast of Barlovento, especially the area around Curiepe, was another attractive destination. ${ }^{21}$ Runaway slaves put into place a sophisticated trans-colonial network to navigate the process of emigrating from slavery on the small Dutch island to freedom in Spanish America. Some slaves left the island openly by forging documents or posing as freemen and women; others surreptitiously stowed away on sea-craft (Klooster 1998:68-9). Many seafarers simply jumped ship once they reached a mainland port.

After finding sympathetic ship captains and crew members in Willemstad and safely crossing the waters to Tierra Firme without being captured, the new arrivals faced a variety of tasks in their new homeland. They had to identify, arrive at, and settle into mainland communities that would welcome (or at least not be hostile to) them; learn a new language and culture; negotiate the complexities of an unfamiliar legal system; and find the necessary support system in Tierra Firme - including lawyers to argue their cases, witnesses to testify on their behalf in court, and priests to baptize them (Castillo 1981:603). ${ }^{22}$ We do not know how many fugitives pursued their cases in Venezuelan courts or what percentage of those who did successfully obtained their legal freedom. Many who sought

20 For a detailed list of 585 slaves who fled from Curaçao to Tierra Firme between 1729 and 1775 see Nationaal Archief Nederland (NAN) Nieuwe West Indische Compagnie (NWIC) 1166:124 (07-08-1775)

21 See, for example, among others, AGN, Archivo del Registro del Distrito Federal, Tierras 1767-M \#1; NAN Oud Archief Curaçao (OAC) 1548:60 (14-01-1739); AGI Santo Domingo (SD) 782, 1732-33; AGN D VXIII \#10, 1736.

22 For a detailed description of the process and mechanisms of marronage, see Gonzalez 1987:127-130 (01-02-1752). 
freedom across the imperial divide never bothered to legalize their status. ${ }^{23}$ Many maintained close ties with Curaçao and participated actively in smuggling even after they moved to Tierra Firme. Spanish intentions notwithstanding, the fugitives seem to have had no compunction about trading with Curaçaoan merchants and engaging in contraband. ${ }^{24}$

Dozens of cases in the archives attest to the tenacity and creativity of those who litigated to obtain their freedom, and the many locals who assisted them in their endeavours. Successful suits required someone who was well versed in the relevant Spanish legal codes, strategies, and precedents. Many cases show a clear understanding of the subtleties required to game the system, with fugitives and their advocates employing a range of tactics to win the ultimate prizes of manumission and land. For example, three men who arrived in Coro from Curaçao in 1740 took six years of legal manoeuvring to gain their freedom, and they changed their story several times along the way to enhance their case. After initially testifying that they already were Catholic and remaining in jail for several years, all three subsequently claimed that they had come to the mainland to escape from 'heretical owners' and that they sought 'the sacred waters of baptism', to be accepted into 'the one true faith' ${ }^{25}$ They then enlisted a local priest to (re)baptize them, and soon thereafter won their freedom, both from jail and from slavery.

An elaborate dance played out within the Spanish colonial legal system, one which often involved years of complicated proceedings and multiple court cases, in which colonial authorities, fugitives, court personnel, Roman Catholic clergy, and witnesses duly certified the conversions and baptisms of people who already were Catholic. A host of other middle sectors, including lawyers, scribes, and clerks, as well as general character witnesses drawn from the wider community, were also involved in the fugitives' quest for legal freedom. ${ }^{26}$ In some cases freedom was granted and then revoked multiple times, sometimes on a technicality, other times on more substantive issues. Such cases could drag on for years, or even decades. ${ }^{27}$ The voluminous paperwork left by these cases

23 For example, NAN OAC 318, Jean Rodier et al. (14-04-1766).

24 See, for example, AGN D VXIII \#10 (1736).

25 Archivo Histórico Nacional, Madrid, Spain (ANH) Vol. 1740 G \#283 Arch. 1. Similar wording appears in many such cases.

26 See the following in Gonzalez 1987:122-3, 125-6, 132; Torres 1997: 'Autos seguidos por María Francisca de Nieto', July 1738-Oct. 1743 (1743-BSWS, Exp. 3:85); 'Autos formados por Juan Joseph', Jan.-July 1753 (1753-JP, Exp. 1:92).

27 See, for example, AANH Archivo del Registro del Distrito Federal, Cajas Negras (ARDFCN) $1787-\mathrm{A} 1$. 
often involved suits and counter-suits, testimony for and against the fugitive by a cross section of the local population, and a variety of sophisticated legal manoeuvres and arguments. Fugitives marshalled extensive local resources to bolster their claims, as did those who fought them in court.

\section{INTER-COLONIAL CONNECTIONS}

Upon arriving in Tierra Firme many Afro-Curaçaoans established links with existing communities of Afro-Venezuelans, including rural maroon settlements, groups of urban freemen and women, and enslaved agricultural labourers, many of whom were involved in smuggling. ${ }^{28}$ These relations were complex and multi-faceted. Venezuelan archives are filled with legal proceedings that pitted Afro-Curaçaoans and locally-born blacks against each other. ${ }^{29}$ AfroVenezuelans were often hostile to the special privileges that the runaways from Curaçao received, especially their access to manumission and land through conversion, options which were closed to them. Local slaves sometimes testified that an immigrant's conversion was bogus, an accusation that probably was true more times than not, but was frequently ignored by the courts. On occasion fugitive Curaçaoans and locally-born blacks fought intensely over property rights. ${ }^{30}$ Sometimes local slaves could receive their freedom by denouncing smugglers; fugitive Afro-Curaçaoans were an easy target. ${ }^{31}$

The number of fugitive slaves from Curaçao had a major social, cultural, and economic impact on entire areas of Tierra Firme. Curaçaoans made up at least thirty per cent of the original inhabitants of Curiepe, a town of free blacks that mainland authorities had established on the north-eastern coast as a buffer against enemy attack in 1721, and where dozens of fugitive Afro-Curaçaoans acquired land and planted small cacao groves in the early to mideighteenth century (Castillo 1981:375-83). The thriving neighbourhood of Guinea, located on the southern outskirts of the town of Coro, was a magnet for fugitive slaves from Curaçao, and the only part of the town that saw steady demographic increase in the eigh-

28 NAN OAC 806: \#622-624 (22-06-1737); Castillo 1981:342, 381; Gonzalez 1987:124.

29 For example, 'Capitan Juan Marcos Marin, Moreno Libre Contra Jose Miguel de Soto, Moreno Libre’: Castillo 1981:312-5.

30 Castillo1981:376-7 and Chapter XVIII.

31 AGN D XLII \#12. 
teenth century (Gonzalez 1990:96). Curaçaoans were such a large percentage of Coro's black population that some Venezuelan historians consider them to have made a significant contribution to the area's ethnic composition (Gonzalez 1987:23). By the end of the eighteenth century over 400 Afro-Curaçaoans had settled in the hills around Coro. ${ }^{32}$ Many of them lived in Santa María de la Chapa, a maroon community that was established in the surrounding mountains at mid-century (Gonzalez 1990:50, 52). The last names of many residents were some variation of the name Curaçao. ${ }^{33}$ Place names are also revealing; church records identified the town as Sta. María de los Negros de Curazao - 'Santa María of the blacks of Curaçao' (Gonzalez 1990:5).

Many fugitives and their descendants became small-scale independent farmers, producing crops such as cacao for the thriving contraband trade. Many retained close ties to Curaçao. ${ }^{34}$ Some were enlisted to help Spanish colonial authorities defend the isolated coast from the incursions of rival European powers and individual freebooters, either by being conscripted into free black militias, or by becoming founding members of new towns of free blacks, or both. In 1745 Curiepe's free blacks were commissioned to fight against smugglers in spite of - or perhaps because of - the town's close ties to the island. ${ }^{35}$ But the very circuits that brought freedom to some people of African descent were also used to snatch it from others (González 1987:81-82, 126). The number and influence of the enslaved Curaçaoan runaways deeply concerned colonial authorities in Tierra Firme, occasionally provoking serious diplomatic tensions, and generating an extensive paper trail of official efforts to return to Curaçao those fugitives who had not legalized their status, and counter-efforts to prevent this, in cases that could drag on for years. ${ }^{36}$ If a Curaçaoan owner petitioned in a mainland court for the return of a fugitive before the slave had legally filed for freedom, Spanish colonial authorities would proceed with the extradition. For people of African descent, then, the trans-colonial exchange circuit could be an extension of enslavement as well as a path to freedom.

32 AGN D XVIII: 1773 \#4; AGN D XLI: 1771: \#3, \#6; Castillo 1981:605.

33 For example, Francisco Curasao is co-petitioner on documents dealing with the loss of a sloop in Coro, 3-12-02-1730 (Gonzalez 1987:123); three men with the last name Curazao appear on the list of people implicated in the 1795 slave uprising in Coro, Rafael Diego Mérida report, 25-06-1795 (Troconis 1969:311); there are sixteen people with the last name Curazao or Curazado in the onomastic index of Castillo 1981.

34 NAN OAC 1548:60 (14-01-1739); AGI Santo Domingo (SD) 782 (1732-3).

35 Castillo 1981:508. For the role of Curiepe's inhabitants in contraband trade: AGN D VXIII $\# 10,1736$.

36 Gonzalez 1987:22-124,140-1; NAN OAC 820:17-30 (11-01-1749). 
Religious ties between Curaçao and Tierra Firme strengthened throughout the eighteenth century, spurred by the sustained, direct contact between the majority populations of African descent, as well as by the institutional framework of the Roman Catholic Church. Catholic clergy who spent time on the island maintained communication with supervisors, fellow clergy, and parishes in Tierra Firme, as well as with their respective hierarchies and with clerical networks fanning across the Americas and beyond. These connections were sanctioned fully by Spanish authorities, and they were at least tolerated by WIC officials. Priests developed and maintained an important network between the two areas; their high degree of mobility allowed them to parlay religious links into economic and socio-cultural contact. Roman Catholic clergy, who were allowed to travel relatively freely across the imperial divide and enjoyed widespread respect among large sectors of the population on both sides, were particularly well-positioned to make contacts and engage in illicit commerce, as well as to promote socio-cultural and religious contact. ${ }^{37}$ The inherently transatlantic, inter-imperial character of Catholic clerical networks, including the fact that many felt their primary alliance to the Holy See in Rome and/or to their respective religious orders rather than to secular authorities in Madrid or Caracas, facilitated economic exchanges outside official circuits. Within this framework people of African descent developed their own trans-colonial religious networks. In the $1760 \mathrm{~s}$ and ' $70 \mathrm{~s}$, for example, several religious brotherhoods (cofradias) in Coro had direct ties to similar societies in Curaçao, and some even had members who lived on the island. The Cofradía del Carmen in Coro sent a delegation to the island, which remained there for six months (Gonzalez 1990:38). At least some members of the brotherhood in Coro likely were fugitives from Curaçao and their descendants.

Beginning in the 1760 s, religious and secular authorities in the Dutch and Spanish realms engaged in a decade-long power struggle to control the Roman Catholic Church structure on the island and thus manage the religious life of the black Catholic majority (Felice 1982:405-11). Spanish authorities formally petitioned the WIC to allow the Bishop of Caracas to appoint priests to the island, or at least to require that the island governor not accept any priest who had not first presented his credentials to the Bishop of Caracas. Although this had been the de facto modus operandi for decades it was an extraordinary request to make officially, considering that the Dutch had held undisputed 
sovereignty over the island since the Peace of Westphalia in 1648. Not surprisingly, company officials demurred, and they further insisted that thereafter only Dutch priests be sent to the island. The Spanish Council of the Indies countered that the Bishop of Caracas retained the exclusive right to designate priests for Curaçao, citing both the extensive historical precedent and, perhaps rather oddly, selected passages in the treaties of Westphalia and Utrecht that guaranteed the free practice of religion to denizens of colonial areas that changed imperial domain (Felice 1982:410). ${ }^{38}$ Continued diplomatic wrangling produced an extensive paper trail but no clear diplomatic resolution. In 1773 Bishop Martí brazenly proclaimed that 'the islands of Curazao, Aruba and Bonayre belong to this parish of Coro and to the Bishopric of Caracas' (Gonzalez 1990:39). Three years later a group of eight Dutch Franciscans arrived to take charge of the Roman Catholic Church on the island, which their order controlled continuously until 1820 (Felice 1982:410; Lampe 2001a:131). Individual Roman Catholic priests regularly continued to visit from Tierra Firme, however.

\section{CONTRABAND AND COLLUSION}

As the century progressed, increased repression of contraband trade shaped patterns of popular resistance in Tierra Firme. The formation of the Real Compañía Guipuzcoana de Caracas (or Caracas Company) in 1728 was a catalyst for resistance. This Basque-owned company was one of Spain's most ambitious and comprehensive attempts to limit illicit trade and channel its wealth directly to the royal treasury. ${ }^{39}$ The Caracas Company established a coast guard that was authorized to intercept and repress suspected smugglers and confiscate their vessels along hundreds of miles of the Caribbean littoral. ${ }^{40}$ This met with immediate resistance from the many different people who were involved in illicit inter-colonial trade. There were at least six major rebellions in cacao-producing areas during the fifty-six years of the company's existence. ${ }^{41}$ These disturbances provide clear evidence of the close relations that developed

38 The cited passages in the treaties dealt with allowing freedom of religion among colonial inhabitants rather than with establishing religious jurisdiction or chain of command.

39 Hussey 1934; Aresti 1963; Vivas 1998.

40 NAN NWIC 1154:62 (07-09-1726); NAN NWIC 1154:67 (12-03-1727); NAN NWIC 1154:74

(01-09-1727).

41 Felice 1977:39-92; Brito 1985:209-36, 1961; Morales 1955; Ferry 1989: Chapter 5. 
between the different participants in the contraband trade. Smuggling sometimes proved to be a unifying force, trumping race, ethnicity, social class, and colonial affiliation. Smugglers often parlayed their inter-colonial contact into collusion against those who would limit the trade.

The first of the revolts broke out in 1730, soon after the Caracas Company began patrolling the Caribbean coast of Tierra Firme. It was led by Andrés López del Rosario, alias Andresote, a mixed-race Venezuelan of African and indigenous descent who had close ties to the trade with Curaçao. ${ }^{42}$ This uprising of slaves, free blacks, mulattos, and native people was directed against the Caracas Company and the colonial authorities who were trying to curtail smuggling. It had the full support of local whites, including elite landholders. At its height participants took over several towns and blockaded roads in the Yaracuy Valley, a major contraband area and site of the thriving smuggling settlement of Tucacas. Most of the Yaracuy Valley's inhabitants, including local officials, enslaved plantation workers, indigenous people, and maroons, as well as white farmers, rightly felt that their entire livelihood was jeopardized by the Caracas Company's crackdown on smuggling. Curaçaoan traders, who also felt threatened by the Caracas Company's activities, provided critical support to the rebels, trading arms and alcohol to them in exchange for cacao (Brito 1985:209). When officials sent in several thousand troops to intensify repression of the uprising, Curaçaoan smugglers whisked the rebel leader Andresote off to the nearby island where he remained at least until $1739 .{ }^{43}$ In the subsequent trials several residents of Tierra Firme testified that they had taken Andresote to Curaçao several times to purchase goods prior to the revolt. ${ }^{44}$

The uprisings in Tierra Firme were also connected to deeper currents that swept through the Atlantic world during the second half of the eighteenth century. As early as the 1740s, stories began to circulate among Tierra Firme's blacks that the Spanish Crown had issued an order to free all slaves throughout the empire, but

42 The Venezuelan historiography is divided on Andresote's status. Brito claims he was born a slave but had joined maroon communities years before the uprising; others say he was free, either by birth or manumission. His status at birth would have depended on that of his mother. Brito 1985:209, 1961:47-9; Felice 1952; 1977:33-8; Hussey 1934:66-9.

43 NAN OAC 1548:60 (14-01-1739); AGI Santo Domingo 782, 'Rebelión del zambo Andrés Bota' (1732-33).

44 The trial transcripts are in AGI Santo Domingo 270, 781, 782. Also see Troconis 1969:24650. One must read such testimonies with a healthy dose of scepticism, however, since the witnesses would have had little to lose by fabricating or exaggerating such ties, and stood to improve their own situation if they fed authorities the information the latter hoped to hear. 
that local authorities were refusing to comply (Felice 1977:72). Given the Crown's history of issuing several reales cédulas that granted freedom to fugitive slaves from Curaçao (and elsewhere) and to slaves who were smuggled into Tierra Firme, a more general emancipation was not outside the realm of imagined possibilities. These rumours intensified later in the century. ${ }^{45}$ Between the 1770s and 1790s an enslaved healer named Cocofío often absented himself from his master, travelling around the mainland countryside insistently proclaiming that a Spanish Royal Decree had freed the slaves but was being suppressed by local authorities. After Cocofío's death the rumours persisted, allegedly fanned by fugitive slaves from Curaçao, who brought more reliable news from the port of Willemstad of the French and Haitian revolutions, including repeated reports from black seafarers that slaves had been freed elsewhere in the Caribbean (Brito 1961:219). ${ }^{46}$ This social unrest was intensified by a changing economic situation. By the end of the eighteenth century it became increasingly difficult for people of African descent, including fugitives from Curaçao, to obtain land in Tierra Firme. In response to the exploding Atlantic market for chocolate, Tierra Firme's lucrative cacao plantations were increasingly concentrated into larger holdings that were held by fewer families and worked by larger numbers of slaves (Brito 1961:60, 63).

By the last decades of the century the geopolitical usefulness of fugitive slaves in Tierra Firme was also shifting. Increasingly the Spanish Crown and local authorities saw them as a threat rather than as a needed infusion of labour. In 1771 the commander of the Caracas battalion warned of 'the suspicion and fear which is being caused by the continued flight of black slaves from Curaçao' (Gonzalez 1990:52). In 1789 Spain allowed free trade in enslaved Africans to some of its American colonies, including Venezuela. ${ }^{47}$ This eliminated, at least in theory, the need both for the asiento and for the parallel contraband trade in slaves (although it is not entirely clear how this played out, especially in the short term, and whether, in fact, it immediately led to the cessation of the illicit trade in enslaved labour). Spain's offer of freedom to enslaved fugitives from rival Protestant powers had outlived its usefulness.

45 For more about the role of these rumours see Klooster's article is this volume.

46 For analysis of the role of maritime communications networks in the Caribbean during the Haitian Revolution see Scott 1986.

47 'Real Cédula de su Magestad Concediendo Libertad para el Comercio de Negros con las Islas de Cuba, Santo Domingo, Puerto Rico, y Provincia de Caracas', 28-02-1789 (reproduced in Marley 1985 Document X: no pagination). 
In 1790 Venezuelan authorities denounced slaves born in Curaçao as 'detrimental to these provinces', articulating a sharp break with previous policies that had welcomed them over eight decades (Acosta 1961:39).

By the early 1790s, increasingly concerned about the widespread travels of people of African descent around the Caribbean and the potential impact of news of the developing French and Haitian revolutions, the Spanish Crown rescinded all the Royal Decrees that had granted freedom to runaway slaves throughout the Americas. The new law applicable to the Dutch sphere, promulgated in 1791, specifically noted the close relationship between marronage and contraband trade in the area between Curaçao and Coro (Torres 1997:50). That same year Spain and the Dutch Republic also signed an agreement for 'the reciprocal restitution of fugitives' (De Granda 1973:6-7). Foreign fugitives were now seen as a threat to Spanish colonial interests rather than as useful geopolitical pawns or as a way to increase the number of loyal subjects.

It is in this context of well-established, overlapping inter-colonial networks - networks in which people of African descent played a central role - that one must situate the slave uprisings that occurred in Curaçao and Coro in the summer of 1795, just three months apart. In May 1795 Venezuela's largest slave revolt of the colonial era broke out in the hills around Coro, an area that was home to hundreds of fugitive Afro-Curaçaoans and their descendants. ${ }^{48}$ Leaders of the uprising had close ties to Curaçao, which saw its own largest slave revolt just three months later. Local authorities in both places claimed that the two rebellions were linked, a charge that has sparked spirited debate in the Venezuelan historiography, with some focusing on the influence of outside agitators, especially those with links to Haiti, and others prioritizing local and regional factors (Rivas et al. 1996; Arcaya 1949). One of the leaders of the Coro rebellion, José Caridad González, was himself an inter-colonial fugitive. Born in West Central Africa (records identify him as Loango, although it is not clear what this term actually meant ${ }^{49}$ ), he was taken to Curaçao by Dutch slavers sometime at mid-century, then escaped to Venezuela, where he subsequently helped other Afro-Curaçaoans flee to freedom along a well-estab-

48 AGN D LXIX \#7.

49 Spanish colonial documents in Tierra Firme frequently used the term 'Loango' to refer to any slave who came through Curaçao; the phrase 'los loangos de Curaçao', for example, is frequently used in reference to the inhabitants of Santa María de la Chapa. It is unlikely that this term was a precise indication of either ethnicity or African provenance. 
lished route travelled by hundreds of Afro-Curaçaoans. In Tierra Firme, González also worked to defend the lands of free blacks (including some Curaçaoans) from the incursions of white landholders; on at least one occasion he travelled to Spain to procure a Royal Decree supporting the small-scale landowners. The other leader of the revolt, José Leonardo Chirinos, was a freeman who worked on cacao plantations and had direct links to the contraband trade with Curaçao (Brito 1985:225-226; Castillo 1981:603). There is evidence that Chirinos travelled regularly to Curaçao and also to Saint-Domingue in the early 1790s (Documentos 1997:186; Brito 1985:225-6).$^{50}$ Whether or not there was a direct conspiracy, it is clear from the participation of people like González, Chirinos, and others that the mainland uprising involved people who had close, ongoing ties to Curaçao. Thus, one may reasonably surmise that the two revolts were connected at some level. Enslaved people who travelled between the two areas certainly would have carried news about rising discontent and perhaps even plans to organize resistance in both places. Given the well-established communication circuits between Curaçao and Coro, word of the Coro uprising and the subsequent repression likely reached Curaçao before the island's August revolt.

While we probably will never know with certainty the exact degree and type of collaboration that existed between the rebels in Curaçao and Coro, perhaps we are missing the point if we focus too narrowly on the intriguing possibility of a slave conspiracy. By 1795 people of African descent in both areas had been part of extensive, over-lapping, inter-colonial networks for well over a hundred years. Through these networks they forged deep, multi-faceted, on-going ties that included economic, religious, and socio-cultural dimensions. The largest slave uprisings in the southern Caribbean occurred in close succession in two places, which, although they belonged to separate imperial spheres, were closely linked through smuggling, migration, and various other forms of exchange. As Lauren Benton has noted, early modern empires often were 'encased in irregular, porous, and sometimes undefined borders' (Benton 2010:2). The irregular, porous, and often undefined imperial boundaries between Curaçao and Tierra Firme created opportunities for people of African descent to develop extra-official intercolonial economic, political, legal, and religious networks. By participating in these networks they, in turn, shaped the contours of each developing colonial society.

50 For Chirinos's testimony following the uprising, which includes information about ties to Curaçao and to the contraband trade: AANH A16-C54-D11182. 
4 Inter-colonial networks and revolutionary ferment, Curaçao and Tierra Firme

BIBLIOGRAPHY

Acosta Saignes, Miguel

1961 La trata de esclavos en Venezuela. Caracas: Centro de Estudios Históricos.

Aizpurua, Ramón

1993 Curazao y la costa de Caracas: Introducción al estudio del contrabando de la provincia de Venezuela en tiempos de la Compañia Guipuzcoana 1730-1788. Caracas: Biblioteca de la Academia Nacional de la Historia. [Fuentes para la Historia Colonial de Venezuela no. 222.]

2002

'En busca de la libertad: Los esclavos fugados de Curazao a Coro en el siglo XVIII', in: Influencias africanas en las culturas tradicionales de los paises andinos: Memorias, pp. 69-102. Bogotá: Dupligráficas.

Arauz Monfante, Celestino Andrés

$1984 \quad$ El contrabando Holandés en el Caribe durante la primera mitad del siglo XVIII. Vol. 1 and 2. Caracas: Biblioteca de la Academia Nacional de la Historia. [Fuentes para la Historia Colonial de Venezuela 168 and 169.]

Arcaya, Pedro Manuel

1949 Insurrección de los negros de la Serranía de Coro. Caracas: Instituto Panamericano de Geografía e Historia Comité de Origenes de la Emancipación. [7.]

Aresti de Amezaga, Vicente

1963 Hombres de la Compañia Guipuzcoana. Caracas: Banco Central de Venezuela.

Benton, Lauren

2010 A search for sovereignty: Law and geography in European empires, 1400-1900. Cambridge: Cambridge University Press.

Brada, Willebrordus M., O.P.

1953 Bisdom Coro, 1531-1637. Willemstad: n.p.

1956 Prefect Caycedo, 1715-1738. Willemstad: n.p.

Briceño Perozo, Mario

1965 'Estudio preliminar', in: Pedro José de Olavarriaga, Instrucción general y particular del estado presente de la provincia de Venezuela en los años de 1720 y 1721. 76:41-51. Caracas: Biblioteca de la Academia Nacional de la Historia.

Brito Figueroa, Federico

$1961 \quad$ Las insurrecciones de los esclavos negros en la sociedad colonial venezolana. Caracas: Cantaclaro. 
Castillo Lara, Lucas Guillermo

1981

Apuntes para la historia colonial de Barlovento. Caracas: Biblioteca de la Academia Nacional de la Historia. [Fuentes para la Historia Colonial de Venezuela 151.]

Documentos de la insurrección

Documentos de la insurrección de José Leonardo Chirinos. Vol. 2.

Caracas: Fundación Historia y Comunicación.

Enthoven, Victor

2003

'Early Dutch expansion in the Atlantic region, 1585-1621', in: Johannes Postma and Victor Enthoven (eds), Riches from Atlantic commerce: Dutch transatlantic trade and shipping, 15851817, pp. 17-47. Leiden: Brill.

Felice Cardot, Carlos

1952 La rebelión de Andresote: Valles del Yaracuy, 1730-1733. Caracas: Imprenta Nacional.

1977 Rebeliones, motines y movimientos de masas en el siglo XVIII venezolano, 1730-1781. Caracas: Academia Nacional de la Historia.

1982 Curazao hispánico: Antagonismo flamenco-español. Caracas: Ediciones de la Presidencia de la República.

Ferry, Robert J.

1989

The colonial elite of early Caracas: Formation and crisis, 15671767. Berkeley: University of California Press.

Gehring, Charles T. and J.A. Schiltkamp (comps)

1987 New Netherland documents. Vol. 17. The Curaçao Papers 1640-1665. Interlaken, NY: Heart of the Lakes.

Gonzalez Batista, Carlos

1997 Documentos para la historia de las antillas neerlandesas. Archivo Histórico de Coro, Fondo Registro Principal I. Coro: Centro de Investigaciones Históricas Pedro Manuel Arcaya.

1990 Antillas y Tierra Firme: Historia de la influencia de Curazao en la arquitectura antigua de Venezuela. Caracas: Refinería Isla (Curazao) S.A.

Goslinga, Cornelis Ch.

1985 The Dutch in the Caribbean and in the Guianas 1680-1791.

Assen: Van Gorcum.

Granda, Germán de

1973 'Papiamentu en Hispanoamérica (Siglos XVII-XIX)', Boletín del Instituto Caro y Cuervo XXVIII-1:1-13. 
Haviser, Jay B.

1987

Amerindian cultural geography on Curaçao. PhD thesis, Leiden University.

Heijer, Henk den

2003

'The Dutch West India Company', in: Johannes Postma and

Victor Enthoven (eds), Riches from Atlantic commerce: Dutch transatlantic trade and shipping, 1585-1817, pp. 77-112. Leiden: Brill.

Hussey, Roland Dennis

1934

The Caracas Company, 1728-1784: A study in the history of Spanish monopolistic trade. Cambridge, MA: Harvard University Press.

Klooster, Wim

1998

Illicit riches: Dutch trade in the Caribbean 1648-1795. Leiden: KITLV Press.

Lampe, Armando

2001a 'Christianity and slavery in the Dutch Caribbean', in: Armando Lampe (ed.), Christianity in the Caribbean: Essays on Church history. Barbados and Jamaica: University of the West Indies Press.

$2001 b$

Mission or submission? Moravian and Catholic missionaries in the Dutch Caribbean during the 19th century. Göttingen: Vandenhoek and Ruprecht.

Marley, David (comp)

1985 Reales asientos y licencias para la introducción de esclavos negros a la América Española, 1667-1789. Windsor, Ontario: RolstonBain. [Colección documenta novae hispaniae vol. B-9.]

Morales Padrón, Francisco

1955 Rebelión contra la compañia de Caracas. Seville: Escuela de Estudios Hispano-Americanos de Sevilla.

Oostindie, Gert (ed.)

1996 Fifty years later: Antislavery, capitalism and modernity in the Dutch orbit. Pittsburgh: University of Pittsburgh Press.

Postma, Johannes

1990 The Dutch in the Atlantic slave trade, 1600-1815. Cambridge:

Cambridge University Press.

Rivas, Pedro Gil, Luis Dovale Prado and Lidia L. Bello

1996 La insurrección de los negros de la Serranía Coriana, 10 de Mayo de 1795: Notas para la discussion. Caracas: Universidad Central de Venezuela.

Rupert, Linda M.

2006 'Contraband trade and the shaping of colonial societies in

Curaçao and Tierra Firme', Itinerario 30-3:35-54. 
'Marronage, manumission, and maritime trade in the early modern Caribbean', Slavery E Abolition 30-3:361-82.

Schmidt, Benjamin

2009 The Dutch Atlantic: From provincialism to globalism, in: Jack P. Greene and Philip D. Morgan (eds), Atlantic history: A critical appraisal, pp. 163-87. Oxford: Oxford University Press. Schunk, Christine W.M.

1990 'The lost Catholic houses of prayer in Curaçao', in: Henry E. Coomans et al, (eds), Building up the future from the past: Studies on the architecture and historic monuments in the Dutch Caribbean. Zutphen: Walburg Press.

1997

"Michael Johannes Schabel S.J., "Notitia de Coraçao, Bonayre, Oruba", 1705 and "Diurnum (1707-1708)", Archivum Historicum Societatis Iesu LXVI-131:89-162.

Scott, Julius S.

1986 The common wind: Currents of Afro-American communication in the era of the Haitian Revolution. PhD thesis, Duke University.

Seed, Patricia

1995 Ceremonies of possession in Europe's conquest of the New World, 1492-1640. Cambridge: Cambridge University Press.

Torres Pantín, Cármen (comp)

1997 Indice sobre esclavos y esclavitud: Sección civiles-scalvos. Caracas: Biblioteca de la Academia Nacional de la Historia Serie Archivos y Catálogos. [11.]

Troconis de Veracoechea, Ermila (comp)

1969 Documentos para el estudio de los esclavos negros en Venezuela. Caracas: Biblioteca de la Academia Nacional de la Historia. [Fuentes para la Historia Colonial de Venezuela 103.]

Vivas Pineda, Gerardo

1998 La aventura naval de la Compañia Guipuzcoana de Caracas. Caracas: Editorial Exlibris.

Watlington, Francisco

2003 'The physical environment: Biogeographical teleconnections in Caribbean prehistory', in Jalil Sued-Badillo (ed.), Autochthonous societies: General history of the Caribbean Volume 1. Paris: UNESCO.

Whitehead, Neil L. (ed.)

$1995 \quad$ Wolves from the sea: Readings in the anthropology of the native Caribbean. Leiden: KITLV Press. 